\title{
Article \\ Indolyl Septanoside Synthesis for In Vivo Screening of Bacterial Septanoside Hydrolases
}

\author{
Aditya R. Pote ${ }^{1,+}\left(\mathbb{D}\right.$, Sergi Pascual ${ }^{2,+}$, Antoni Planas ${ }^{2, *}$ and Mark W. Peczuh ${ }^{1, *}$ \\ 1 Department of Chemistry, University of Connecticut, 55 N. Eagleville Road U3060, Storrs, CT 06269, USA; \\ aditya.pote@gmail.com \\ 2 Laboratory of Biochemistry, Institute Químic de Sarrià, University Ramon Llull, 08017 Barcelona, Spain; \\ sergipascualt@iqs.url.edu \\ * Correspondence: antoni.planas@iqs.edu (A.P.); mark.peczuh@uconn.edu (M.W.P.) \\ + These authors made equal contributions.
}

Citation: Pote, A.R.; Pascual, S.; Planas, A.; Peczuh, M.W. Indolyl Septanoside Synthesis for In Vivo Screening of Bacterial Septanoside Hydrolases. Int. J. Mol. Sci. 2021, 22, 4497. https://doi.org/10.3390/ ijms22094497

Academic Editor: Vladimír Křen

Received: 30 March 2021

Accepted: 23 April 2021

Published: 26 April 2021

Publisher's Note: MDPI stays neutral with regard to jurisdictional claims in published maps and institutional affiliations.

Copyright: (C) 2021 by the authors Licensee MDPI, Basel, Switzerland. This article is an open access article distributed under the terms and conditions of the Creative Commons Attribution (CC BY) license (https:// creativecommons.org/licenses/by/ $4.0 /$ )

\begin{abstract}
Building-up and breaking-down of carbohydrates are processes common to all forms of life. Glycoside hydrolases are a broad class of enzymes that play a central role in the cleavage of glycosidic bonds, which is fundamental to carbohydrate degradation. The large majority of substrates are five- and six-membered ring glycosides. Our interest in seven-membered ring septanose sugars has inspired the development of a way to search for septanoside hydrolase activity. Described here is a strategy for the discovery of septanoside hydrolases that uses synthetic indolyl septanosides as chromogenic substrates. Access to these tool compounds was enabled by a route where septanosyl halides act as glycosyl donors for the synthesis of the indolyl septanosides. The screening strategy leverages the known dimerization of 3-hydroxy-indoles to make colored dyes, as occurs when the $\beta$-galactosidase substrate $X-G a l$ is hydrolyzed. Because screens in bacterial cells would enable searches in organisms that utilize heptoses or from metagenomics libraries, we also demonstrate that septanosides are capable of entering E. coli cells through the use of a BODIPY-labeled septanoside. The modularity of the indolyl septanoside synthesis should allow the screening of a variety of substrates that mimic natural structures via this general approach.
\end{abstract}

Keywords: septanoside; indolyl glycoside; glycosidase; septanoside hydrolase

\section{Introduction}

Glycoside hydrolases (GH) are a broad superfamily of carbohydrate active enzymes that perform important functions in glycobiology-degradation of structural polysaccharides, remodeling of cell-surface proteoglycans and glycolipids, and even activation of small molecule natural products from latent precursor compounds [1-5]. Glycoside hydrolases (also referred to as glycosidases) cleave acetal linkages (glycosides) between a sugar and an aglycone moiety. Classification of GH families is based on the configuration ( $\alpha$ - vs. $\beta-$ ) and location of the hydrolyzed bond (i.e., endo-vs. exo-), the identity of the sugar residue that is cleaved (e.g., D-glucose and D-galactose), and the three-dimensional shape of the hydrolase. The widely used repository of Carbohydrate Active Enzymes (CAZy database, www.cazy.org (accessed on 1 March 2021)) [6] classifies CAZymes in families based on sequence similarity and three-dimensional (3D) folds. Among glycoside hydrolases, there are currently (March 2021) 170 GH families. Members of each family share the same reaction mechanism and 3D fold, but different substrate specificities are found in most of the families, meaning that substrate specificity is dictated by subtle structural differences at the active site. Substrates typically consist of a pyranose or a furanose ring attached to a variety of aglycone species. Seven-membered ring septanose glycosides are all but unprecedented in natural systems $[7,8]$. While they are not true septanosides because the seven-membered ring is not linked through a glycosidic linkage, the recently reported natural products portulasoid 1 and 20-hydroxy-ecdysone septanoside 2 from 
Atriplex portulacoides roots (Figure 1a) [9] open the provocative possibility that other similar structures, in which the polyhydroxy oxepane might be a septanoside (e.g., 4 in Figure 1a), could be discovered. In principle, it might be possible that septanoside hydrolases are present in nature or that promiscuous glycoside hydrolases might also accept septanoside substrates. Indeed, it is known that the seven-member ring iminosugar 1,6-dideoxy-1,6imino-L-iditol was a glycosidase inhibitor [10], and it was reported that 4-nitrophenyl L-idoseptanosides, septanose analogs from hexoses, were substrates of some glycoside hydrolases, albeit weak ones [11].

a

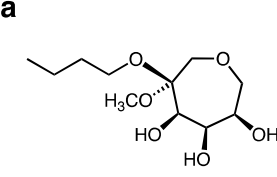

1
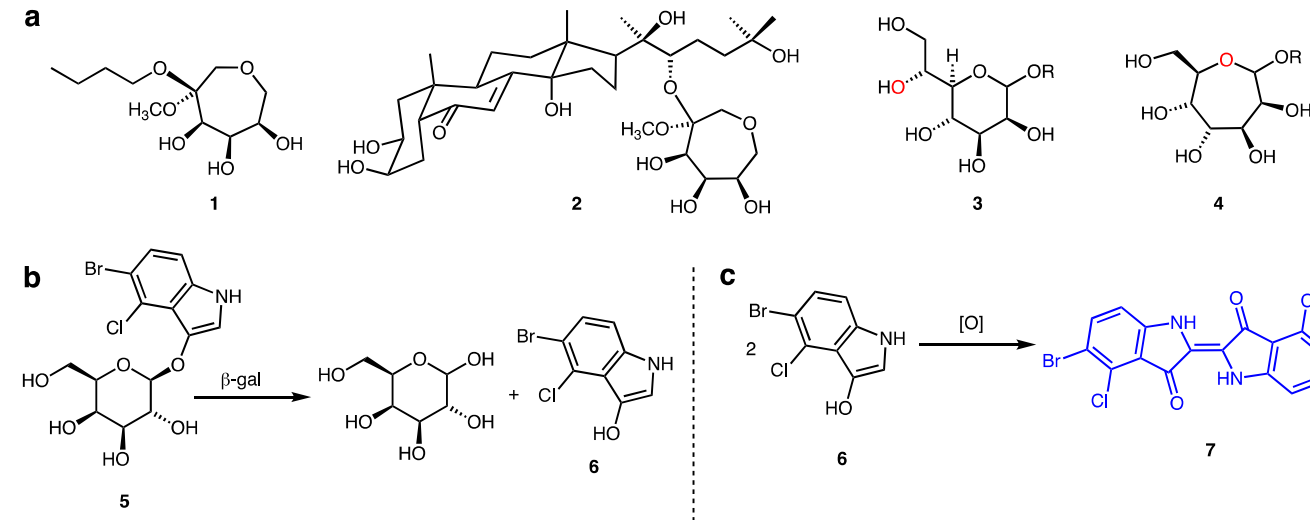

C

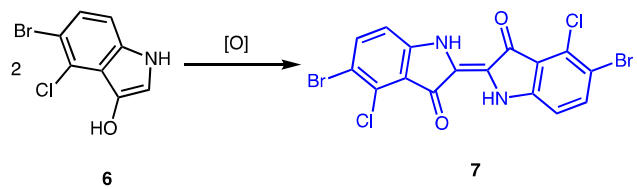

Figure 1. (a) Portulasoid 1 and 20-hydroxy-ecdysone septanoside 2 from Atriplex portulacoides roots; D-glycero-D-mannoheptose in its pyranose (3) and septanose (4) ring forms. (b) Hydrolysis of X-Gal 5, giving rise to D-galactose and 3-hydroxyindole 6. (c) Oxidative dimerization of 3-hydroxyindole 6 to indigo dye 7.

The identification of a naturally occurring septanoside hydrolase or other GH sufficiently promiscuous to hydrolyze septanosides would be an important milestone. Such an enzyme, or mutants thereof, would open up whole new areas of glycobiology research. For example, discovery of a septanoside hydrolase would motivate the search for septanosidecontaining glycoconjugates in the producing organism. Plants are a candidate kingdom in this search because of the discovery of compounds $\mathbf{1}$ and $\mathbf{2}$. An even more promising source, however, might be Gram-negative bacteria. There are numerous examples of heptose-containing glycoconjugates present in Gram-negative species [12,13], with the sedoheptulose/D-glycero-D-manno-heptose (3) biosynthetic pathway being a representative [14]. Cyclization of 3 through its C6 hydroxyl group (red) instead of the C5 hydroxyl could ultimately give rise to septanose glycosides 4 . Biosynthetic pathways involving heptoses are still in the early days of being thoroughly characterized, which also adds an incentive to a search for new glycosyl hydrolases. A first step in any search for septanoside hydrolases, therefore, is the development of tools—an assay strategy and matching substrate- that could be used to identify these enzymes.

One straightforward approach to search for septanoside hydrolases borrows from the $\beta$-galactosidase assay widely used in molecular biology. Upon glycoside hydrolysis of a pro-chromogenic substrate such as 5 -bromo-4-chloro-3-indolyl- $\beta$-D-galactopyranoside 5 (X-Gal) [15], D-galactose is liberated along with 3-hydroxyindole 6 (Figure 1b). Oxidative dimerization of 6 results in the formation of an easily detected indigo dye 7. Development of a blue color in a bacterial colony or culture of when X-Gal is present therefore reports on the presence of the $\beta$-galactosidase enzyme. In practice, the "blue-white colony screen" is frequently applied to the preparation of a protein expression vector [16]. The multiple cloning site where a DNA construct encoding the protein of interest will be inserted is positioned within the $\beta$-galactosidase gene on the plasmid. Plasmids lacking the insert retain a functioning $\beta$-galactosidase and hence lead to blue colonies after transformation. Successful insertion of the construct into the plasmid, on the other hand, disrupts the $\beta$-galactosidase gene and the associated hydrolase activity, giving rise to white colonies after transformation. In the context of our search, we envisioned using indolyl septanosides 
as candidate substrates of putative septanoside hydrolases. If hydrolytic activity toward such a substrate were present in a bacterial colony, we would anticipate the appearance of a characteristic blue color. To that end, we report here the syntheses of indolyl septanoside substrates for the discovery of septanoside hydrolases. Their structures mimic X-Gal, allowing them to be used for in vivo screening of bacteria. We further demonstrate that a related BODIPY-septanoside conjugate is transported into the cytoplasm of E. coli, probably using any of its numerous sugar transporters. Development of these tools constitutes the first steps toward the identification of septanoside hydrolase enzymes.

\section{Results}

\subsection{Synthesis of Indolyl Septanosides}

Indolyl septanosides 8 and 9 (Figure 2a) became the initial targets of substrate synthesis for a few reasons. First among them were the structural analogy of $\mathbf{8}$ and $\mathbf{9}$ to $\mathrm{X}$-Gal 5 and reports on methods for the synthesis and utilization of indolyl glycosides in glycosidase assays [17]. The substitution pattern on the 5-bromo-3-indolyl aglycone was based on the ready availability of the 5-bromo-anthranilic acid starting material and the color of tyrian purple dye (an analog of 7 lacking the chlorine atoms) that arises from its oxidative dimerization $[18,19]$. Further, the stereogenic centers from C3-C6 in $\beta$-configured D-glycero-D-gulo-septanoside 8 and D-glycero-D-ido-septanoside 9 have identical relative configurations as D-glucose from C2-C5. The "phased" correspondence between these centers was important to recognition of septanosides by lectins [20-22]; it refers to the fact that $\mathrm{C} 2$ of the pyranose is the same as the $\mathrm{C} 3$ of the septanose and so forth. We also considered the possible promiscuity of glucosidases as giving us a higher probability of identifying active GHs in our search. The synthetic strategy drew from reported methods for indolyl glycoside synthesis [18,23-25] and our previous experience at preparing septanose glycosides via nucleophilic displacement on anomeric bromides [26]. It leveraged a synthesis of the per-O-acetyl septanose precursors of the anomeric bromides that began from natural D-pyranosides such as D-glucose, suggesting that the route could be extended to other sugars.

Preparation of indolyl septanoside 8 leveraged the known conversion of per-O-acetyl septanose 10 to its corresponding $\alpha$-configured anomeric bromide $\mathbf{1 1}(93 \%$, Figure $2 b)$ [26]. Attempted glycosylation of $\mathbf{1 1}$ via direct displacement $\left(\mathrm{S}_{\mathrm{N}} 2\right)$ conditions with 5-bromoindoxyl (i.e., the analog of $\mathbf{1 2}$ lacking the $\mathrm{C} 2$ carboxylate group) was unsuccessful due to rapid oxidative dimerization of the indoxyl species under the basic reaction conditions $\left(\mathbf{1 1}+\mathbf{1 2}\right.$, potassium tert-butoxide in acetonitrile, $0{ }^{\circ} \mathrm{C}$ to $\left.\mathrm{rt}\right)$. We therefore resorted to a strategy that used 2-carbomethoxy indoxyl $\mathbf{1 2}$ as acceptor. The carbomethoxy moiety at the 2-position of the indoxyl ring is a blocking group that prevents oxidative dimerization during the glycosylation [18]. In the event, glycosylation of $\mathbf{1 1}$ with $\mathbf{1 2}$ gave protected septanoside 13 in $48 \%$ yield; the yield for the glycosylation is modest but was not extensively optimized. Recompense for successful glycosylation in this instance was the multi-step deprotection that had to be undertaken to arrive at the target. Compound $\mathbf{1 3}$ was therefore converted to key intermediate 14 by a sequence that included removal of the acetate protecting groups and the methyl esters in a two-step process. Re-acetylation of the hydroxyl groups in this species was concomitant with decarboxylation of the carboxy group yielding 13 in $73 \%$ over the three steps. It proved convenient to purify 13 at this stage before the final de-acetylation. Removal of the acetates under Zemplén conditions then provided 5-bromo-3-indolyl septanoside 8 in $75 \%$ yield. Overall, the yield of 8 over the six-step sequence was $24 \%$ with an average yield per step of $73 \%$. Compound 9 , the $\mathrm{C} 2^{\prime}$-epimer of 8 , was prepared from per-O-acetyl septanose 15 using the same set of reactions, and shown in Figure 2b, in 35\% yield over the six-step sequence. 


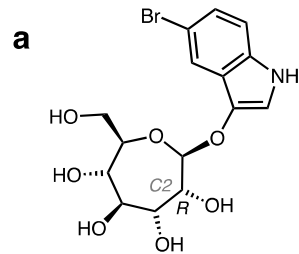

8

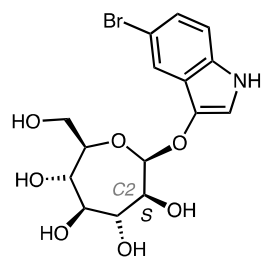

9

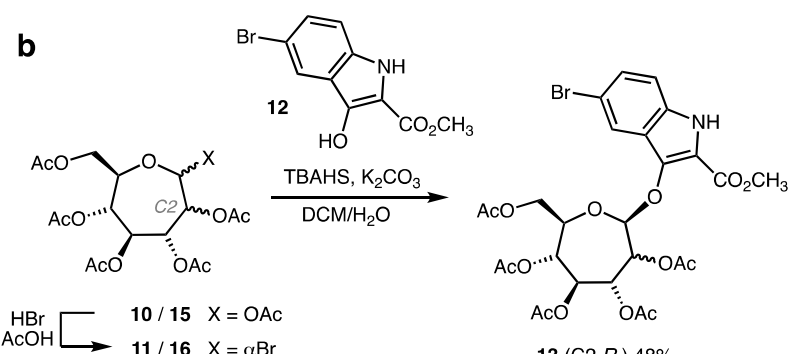

$\stackrel{\mathrm{HBr}}{\mathrm{AcOH}} \longrightarrow \begin{array}{r}10 / 15 \quad \mathrm{X}=\mathrm{OAc} \\ 11 / 16 \quad \mathrm{X}=\alpha \mathrm{Br}\end{array}$
$10 \rightarrow \mathbf{1 1}(\mathrm{C} 2$ R) $93 \% ; 15 \rightarrow 16$ (C2 S) $95 \%$

13 (C2 R) $48 \%$

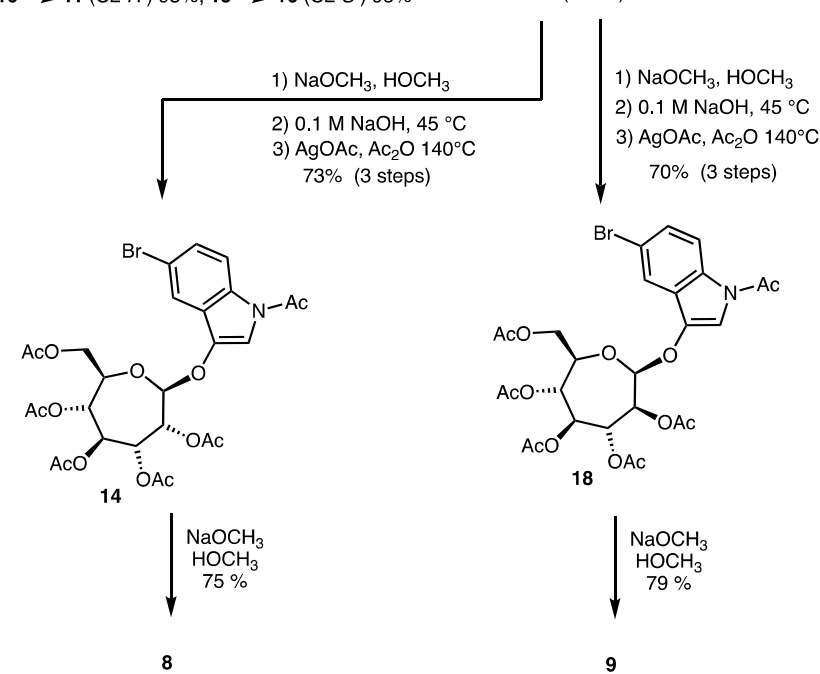

Figure 2. (a) Indolyl septanosides 8 and 9. (b) Synthetic routes, including yields, used to prepare indolyl septanosides 8 and 9.

Indolyl septanoside 8 was characterized both structurally and functionally. NMR spectroscopic data for 8 were consistent with a $\beta$-configured anomeric center $(\mathrm{H} 1 \delta=4.93 \mathrm{ppm}$, $\mathrm{C} 1 \delta=110.1 \mathrm{ppm})$ and a trans disposition of the groups at $\mathrm{C} 1$ and $\mathrm{C} 2\left({ }^{3} J_{\mathrm{H} 1, \mathrm{H} 2}=5.5 \mathrm{~Hz}\right)$. These values were comparable to other 1,2-trans $\beta$-septanosides we have synthesized, including $p$-nitrophenyl (pNP) septanoside 19 (vide infra). Values for the 1,2-cis indolyl septanoside 9 ( $\mathrm{H} 1 \delta=5.09 \mathrm{ppm}, \mathrm{C} 1 \delta=105.5 \mathrm{ppm}$, and $\left.{ }^{3} J_{\mathrm{H} 1, \mathrm{H} 2}=2.3 \mathrm{~Hz}\right)$ were also consistent with its proposed structure $[8,26]$. In a separate line of experimentation, septanoside 9 was exposed to buffer solutions at $\mathrm{pH} 5,6$, and 7 , as well as a $1 \mathrm{M}$ solution of $\mathrm{HCl}$. With standing at room temperature over $8 \mathrm{~h}$, color developed only in the $1 \mathrm{M} \mathrm{HCl}$ samples. We interpreted the results to be a demonstration of the stability of the indolyl glycosides at $\mathrm{pH}$ values near neutrality and in a range where many GH enzymes are active. The results also demonstrated the susceptibility to acid hydrolysis. In a preparative scale experiment, the indigo precipitate that arose from $1 \mathrm{M} \mathrm{HCl}$ hydrolysis of $\mathbf{9}$ was collected, redissolved in $\mathrm{N}, \mathrm{N}$-dimethylformamide, and its UV-vis spectrum compared to a sample of tyrian purple synthesized independently by a different method [27-29].

\subsection{Evaluation of Indolyl Septanoside 8 as a Substrate of Common Exo-Glycoside Hydrolases}

Compound 8 was assayed in vivo with E. coli cells under conditions that are typical for assays that use X-Gal substrate 5. E. coli BL21(DE3) Star cells harboring an inducible 
plasmid overexpressing the E. coli $\beta$-galactosidase (BL21-pGal ${ }^{+}$) and cell harboring an empty plasmid (BL21-pGal ${ }^{-}$) were grown on Petri plates containing compound 8 with isopropyl 1-thio- $\beta$-D-galactopyranoside (IPTG) as inducer. No blue colonies were observed (as opposed to the control BL21-pGal ${ }^{+}$with 7) (Figure 3). At first glance, the apparent lack of activity, as evidenced by the lack of appearance of blue colonies, may reflect that $E$. coli $\beta$ galactosidase did not recognize septanoside 8 . It may also have indicated that the substrate was not internalized into the $E$. coli cells. To test the first scenario, we assayed the purified E. coli $\beta$-galactosidase with compound $\mathbf{8}$ under the same experimental conditions where it shows maximum activity with its cognate substrate (Table 1). Once again, no hydrolytic activity was detected, confirming that septanoside 8 is not a $\beta$-galactosidase substrate.
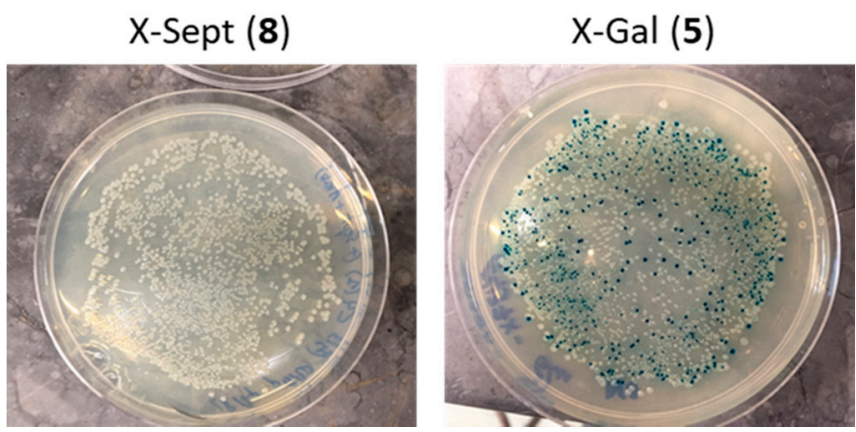

Figure 3. Blue-white colony screen of E. coli BL21(DE3) Star cells with indolyl septanoside 8. BL21(DE3) Star cells harboring a plasmid expressing E. coli $\beta$-galactosidase: (Left) with X-Sept (8) substrate; and (Right) with substrate X-Gal (5).

Table 1. In vitro screen of selected glycosidases.

\begin{tabular}{|c|c|c|c|}
\hline Enzyme & Substrate & S.A. (U/mg) ${ }^{a}$ & Conditions \\
\hline $\begin{array}{l}\beta \text {-Galactosidase } \\
\text { (Escherichia coli) }\end{array}$ & $\begin{array}{c}\text { pNP-Gal } \\
\mathbf{8} \\
\mathbf{9}\end{array}$ & $\begin{array}{c}35 \\
\text { n.d. }{ }^{b} \\
\text { n.d. }\end{array}$ & $\begin{array}{c}\text { Phosphate buffer } \\
\text { (100 mM) pH } 6.5 \\
40{ }^{\circ} \mathrm{C}\end{array}$ \\
\hline $\begin{array}{l}\beta \text {-Galactosidase } \\
\text { (Aspergillus niger) }\end{array}$ & $\begin{array}{c}\text { pNP-Gal } \\
\mathbf{8} \\
\mathbf{9}\end{array}$ & $\begin{array}{c}170 \\
<0.001 \\
\text { n.d. }\end{array}$ & $\begin{array}{c}\text { Acetate buffer } \\
(100 \mathrm{mM}) \mathrm{pH} 4.5 \\
40^{\circ} \mathrm{C}\end{array}$ \\
\hline $\begin{array}{c}\beta \text {-Glucosidase } \\
\text { (Streptomyces sp.) }\end{array}$ & $\begin{array}{c}\text { pNP-Glc } \\
\mathbf{8} \\
\mathbf{9}\end{array}$ & $\begin{array}{l}3.3 \\
<0.005 \\
\text { n.d. }\end{array}$ & $\begin{array}{c}\text { Phosphate buffer } \\
(50 \mathrm{mM}) \mathrm{pH} 6.5 \\
50{ }^{\circ} \mathrm{C}\end{array}$ \\
\hline $\begin{array}{l}\beta \text {-Glucosidase } \\
\text { (Almonds) }\end{array}$ & $\begin{array}{c}\text { pNP-Glc } \\
\mathbf{8} \\
\mathbf{9}\end{array}$ & $\begin{array}{c}2 \\
\text { n.d. } \\
\text { n.d. }\end{array}$ & $\begin{array}{l}\text { Phosphate buffer } \\
\text { (100 mM) pH } 5.0 \\
37^{\circ} \mathrm{C}\end{array}$ \\
\hline $\begin{array}{c}\beta-\text {-Glucosidase } \\
\text { (Thermatoga maritima) }\end{array}$ & $\begin{array}{c}\text { pNP-Glc } \\
\mathbf{8} \\
\mathbf{9}\end{array}$ & $\begin{array}{l}70 \\
\text { n.d. } \\
\text { n.d. }\end{array}$ & $\begin{array}{c}\text { Maleate buffer } \\
(50 \mathrm{mM}) \mathrm{pH} 6.5 \\
40^{\circ} \mathrm{C}\end{array}$ \\
\hline $\begin{array}{l}\text { B-Glucosidase } \\
\text { (Phanerochaete } \\
\text { chyrosporium) }\end{array}$ & $\begin{array}{c}\text { pNP-Glc } \\
\mathbf{8} \\
\mathbf{9}\end{array}$ & $\begin{array}{l}100 \\
\text { n.d. } \\
\text { n.d. }\end{array}$ & $\begin{array}{c}\text { Acetate buffer } \\
(100 \mathrm{mM}) \mathrm{pH} 5.0 \\
40^{\circ} \mathrm{C}\end{array}$ \\
\hline $\begin{array}{l}\beta \text {-Mannosidase } \\
\text { (Cellulomonas fimi) }\end{array}$ & $\begin{array}{c}\text { pNP-Man } \\
\mathbf{8} \\
\mathbf{9} \\
\end{array}$ & $\begin{array}{c}10 \\
<0.001 \\
<0.001\end{array}$ & $\begin{array}{c}\text { Maleate buffer } \\
(100 \mathrm{mM}) \mathrm{pH} 6.5 \\
35^{\circ} \mathrm{C}\end{array}$ \\
\hline $\begin{array}{l}\beta \text {-Glucuronidase } \\
\text { (Escherichia coli) }\end{array}$ & $\begin{array}{c}\text { pNP-GlcA } \\
8 \\
9 \\
\end{array}$ & $\begin{array}{l}110 \\
\text { n.d. } \\
\text { n.d. }\end{array}$ & $\begin{array}{c}\text { Tris } \cdot \mathrm{HCl} \text { buffer } \\
(100 \mathrm{mM}) \mathrm{pH} 7.5 \\
37^{\circ} \mathrm{C}\end{array}$ \\
\hline $\begin{array}{c}\beta-X y l o s i d a s e \\
\text { (Bacillus pumilus) }\end{array}$ & $\begin{array}{c}\mathrm{pNP}-\mathrm{Xyl} \\
\mathbf{8} \\
\mathbf{9}\end{array}$ & $\begin{array}{l}18 \\
\text { n.d. } \\
\text { n.d. }\end{array}$ & $\begin{array}{c}\text { Phosphate buffer } \\
(50 \mathrm{mM}) \mathrm{pH} 7.5 \\
35^{\circ} \mathrm{C}\end{array}$ \\
\hline
\end{tabular}

a Specific activity $(\mathrm{U} / \mathrm{mg})$ at $1 \mathrm{mM}$ pNP-substrates. ${ }^{\mathrm{b}}$ n.d., not detected. 
With the aim of potentially finding an enzyme that was able to recognize septanoside substrates, indolyl septanoside $\mathbf{8}$ was subjected to a panel of glycosidases to test in vitro for their ability to hydrolyze the substrate (Table 1). Each enzyme was assayed at high enzyme concentration (25-50 U/mL, activity units with its cognate substrate) with compounds 8 and $9(1 \mathrm{mM})$ at the $\mathrm{pH}$ optimum of each enzyme. None of them showed measurable activity (by colorimetry of released indigo dye), including the E. coli $\beta$-galactosidase as indicated above. Only the Streptomyces sp. $\beta$-glucosidase (Bgl3) resulted in faint activity. This is a rather promiscuous enzyme reported to hydrolyze aryl glycosides of D-glucose, D-galactose, D-mannose, D-xylose and L-fucose [30]. We then analyzed the activity of Bgl3 against $p$-nitrophenyl septanoside 19, prepared as previously reported [26], in greater detail. At a fixed Bgl3 concentration $(9.2 \mu \mathrm{M})$, initial rates at increasing concentrations of 19 (Figure 4) were fit to give the following kinetics parameters: $k_{c a t}=5.9 \times 10^{-7} \mathrm{~min}^{-1}$; $K_{M}=3 \mathrm{mM} ; h=3.8$. As compared to an efficient Bgl3 substrate (pNP- $\beta$-D-glucopyranoside, $k_{\text {cat }}=13.9 \times 10^{-2} \mathrm{~min}^{-1}, K_{M}=0.8 \mathrm{mM}, K_{i}=0.6 \mathrm{mM}$ ), the data show that 19 is a poor substrate for the glycosidase with a turnover of approximately five orders of magnitude slower than the glucoside.
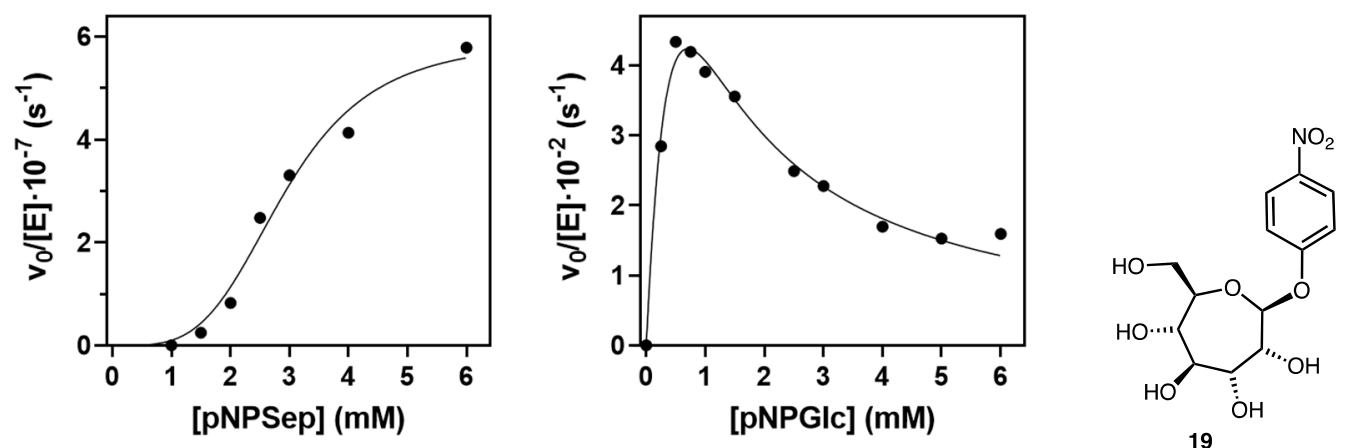

Figure 4. Kinetics of Streptomyces sp. $\beta$-galactosidase (Bgl3) with pNP-Sept (19) and pNP-Glc substrates. Conditions: $50 \mathrm{mM}$ phosphate buffer, $\mathrm{pH} 6.5$, and $50^{\circ} \mathrm{C}$.

\subsection{Transport of a BODIPY-Labeled Septanoside into E. coli Cells}

In search of septanoside hydrolases, we intend to use compound $\mathbf{8}$ for the screening of plant, yeast, and bacterial cell extracts as well as for in vivo "blue-white" screening of bacterial cells harboring libraries of glycoside hydrolases (i.e., metagenomics libraries) [31]. It was necessary, therefore, to return to the question of whether or not 8 was capable of entry into E. coli cells. To that end, we investigated the transport of septanosides into the bacterial cytoplasm. As a proof-of-concept, a BODIPY-labeled septanoside (i.e., 23, Figure 5) was synthesized as a surrogate of compound $\mathbf{8}$ to be used in confocal microscopy studies. BODIPY is a commonly used fluorophore tag that can be used to analyze uptake by cells $[32,33]$ and for cell sorting by fluorescence-activated cell sorting (FACS) [34,35]. A Huisgen click reaction $[33,36]$ between commercially available BODIPY alkyne $\mathbf{2 0}$ and the known septanosyl azide 21 [26] gave protected conjugate 22 in $48 \%$ yield. Deprotection of compound 22 under Zemplén conditions then afforded BODIPY-labeled septanoside 23. 


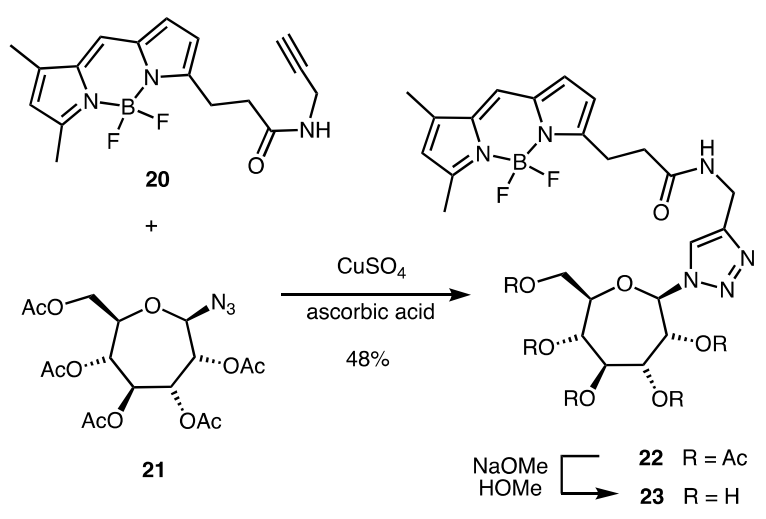

Figure 5. Synthesis of BODIPY-labeled septanoside 23.

Two different E. coli strains, MG1655 and TOP10, were used to analyze cellular uptake by confocal microscopy (Figure 6). Prior to microscopy, cultures were grown to OD 1.0, washed, and then suspended in $10 \mathrm{mM}$ MES buffer at $\mathrm{pH}$ 5.5. An aliquot of this culture was incubated with FM4-64 (localizes into bacterial membrane), BODIPY septanoside 23, and DAPI (DNA stain), and then spun down and resuspended prior to observation. With MG1655 cells, the BODIPY fluorescence clearly localized in the cytoplasm with high intensity, confirming internalization of the septanoside. A lack of BODIPY fluorescence intensity at the cell periphery indicated that the labeled septanoside was not attached to the outer membrane. The merged image in Figure 6 shows the colocalization of the blue and green images, consistent with transport of 23 , which was considered a surrogate for indolyl septanoside 8 in these experiments. Similar results were obtained in experiments with the TOP10 cells, where 23 also localized in the cytoplasm of this E. coli strain (see Supplementary Materials).

DIC

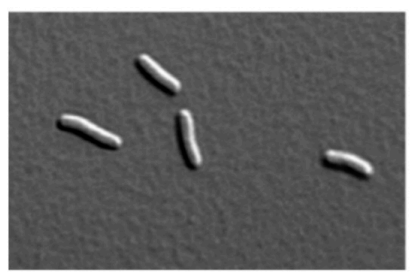

FM 4-64
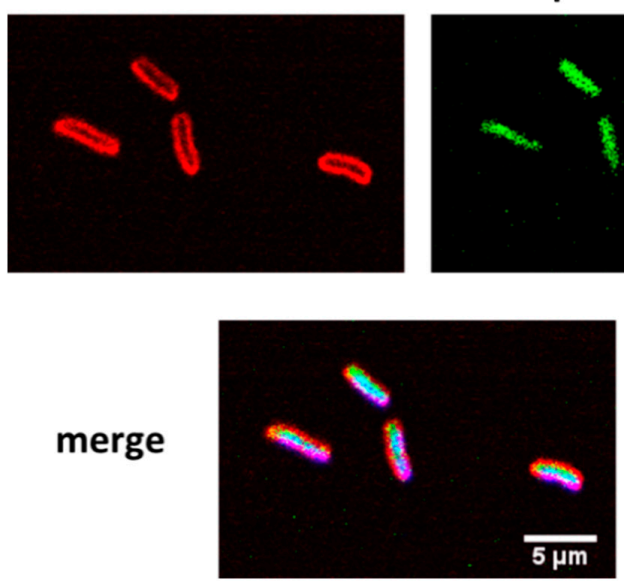

DAPI

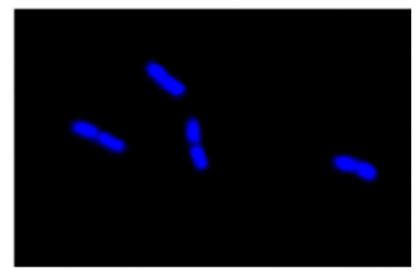

Sept-Bodipy

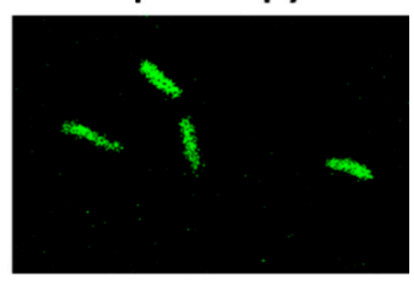

$5 \mu \mathrm{m}$

Figure 6. Confocal fluorescence microscopy of E. coli MG1655 cells with labeling stains. DIC, optical microscopy image; DAPI, DNA staining (bacterial chromosome); FM 4-64, membrane staining; Sept-BODIPY, BODIPY-labeled septanoside (23). Scale bar $(5 \mu \mathrm{m})$ is the same in all images. 


\section{Discussion}

The investigation reported here has established a conceptual framework behind the search for septanoside hydrolases from natural sources. Such a search will allow the identification of catabolic enzymes from organisms such as Atriplex portulacoides that produce polyhydroxy oxepanes (the source of compounds 1 and 2) or Gram-negative organisms that utilize heptoses. Additionally, metagenomics libraries expressed in bacteria such as E. coli can be interrogated as well for hydrolytic activity. Our approach is fundamentally molecular-small molecule synthesis was used to prepare tools that enable searching both in vitro and, critically, in vivo for enzymes. Indolyl septanosides are useful reagents because they enable the colorimetric characterization of glycoside hydrolysis in a manner analogous to X-Gal. Preliminary assays in E. coli to characterize the reactivity of indolyl D-glycero-D-gulo-septanoside 8 as a substrate of $\beta$-galactosidase showed no hydrolysis. The apparent lack of reactivity of this septanoside substrate was subsequently explored along two different lines. First, in vitro experiments with a panel of commercially available glycosidases also showed no significant hydrolysis of the unnatural substrates $\mathbf{8}$ and $\mathbf{9}$. Significantly, Bgl3 ( $\beta$-glucosidase from Streptomyces sp.) showed a suggestive activity with light-pale blue colonies when using substrate 8 . Further analysis with $p$-nitrophenyl septanoside 19 confirmed the low activity, in the range of 5-6 orders of magnitude lower than its $p$-nitrophenyl D-glucoside substrate. In a second line of inquiry, BODIPY-labeled septanoside 23, prepared via click reaction with a septanosyl azide, was observed inside E. coli cells by confocal microscopy. It suggested that septanosides traverse the bacterial envelope. Taken together, these results illustrate an approach that opens the door to a broader search for septanoside hydrolase activity in bacterial systems.

\section{Materials and Methods}

\subsection{General Experimental}

Commercially available starting materials, reagents, and solvents (Sigma-Aldrich, St. Louis, MO, USA and Acros/Thermofisher, Waltham, MA, USA) were used without further purification. Septanosyl azide $\mathbf{2 1}$ was prepared as previously reported [26]. Reactions were performed under nitrogen atmosphere unless otherwise noted and were monitored by TLC using silica gel HL plates w/UV254, 250 m (SiliCycle, Quebec City, PQ, Canada), visualized either under UV lamp or by charring with $2.5 \%$-anisaldehyde in $\mathrm{H}_{2} \mathrm{SO}_{4}, \mathrm{AcOH}$ and EtOH solutions. Reverse phase C18 TLC plates w/UV254, $200 \mu \mathrm{m}$ (Sorbtech, Atlanta, GA, USA) were also used and visualized by UV. Flash chromatography was performed on silica gel $(60 \AA, 40-63 \mu \mathrm{m}) .{ }^{1} \mathrm{HNMR}$ spectra were collected on Bruker NMR instruments at either 400 and $500 \mathrm{MHz}$ with chemical shift referenced to $\left(\mathrm{CH}_{3}\right)_{4} \mathrm{Si}\left(\delta_{\mathrm{H}} 0.00 \mathrm{ppm}\right)$ or the residual peak in $\mathrm{CDCl}_{3}\left(\delta_{\mathrm{H}} 7.24 \mathrm{ppm}\right)$ or $\mathrm{CD}_{3} \mathrm{OD}\left(\delta_{\mathrm{H}} 3.31 \mathrm{ppm}\right) .{ }^{13} \mathrm{C}$ NMR spectra were collected at $100 \mathrm{MHz}$ and referenced to residual peak in $\mathrm{CDCl}_{3}\left(\delta_{\mathrm{C}} 77.2 \mathrm{ppm}\right)$ or $\mathrm{CD}_{3} \mathrm{OD}$ $\left(\delta_{C} 49.1 \mathrm{ppm}\right)$. High resolution mass spectrometry data were collected on a JEOL DART Electrospray-Time-of-Flight (AccuTOF-DART) instrument. Enzymes were purchased from Megazyme Ltd. (Bray, Ireland). $\beta$-Glucosidase from Streptomyces was expressed and purified as reported in [30]. DAPI (4',6-diamidine-2'-phenylindole dihydrochloride) and FM 4-64 (N-(3-triethylammoniumpropyl)-4-(6-(4-(tiethylamino)phenyl)hexatrienyl)pyridinium dibromide) were purchased from Sigma-Aldrich and Thermofisher, respectively.

\subsection{Synthesis of Indolyl Septanosides $\mathbf{8}$ and $\mathbf{9}$}

Phase-Transfer Glycosylation (General Procedure). Freshly prepared per-O-acetyl septanosyl bromide (i.e., 10) [26] (0.306 g, $0.63 \mathrm{mmol})$, tetra- $N$-butylammonium hydrogen sulfate (TBAS, $0.214 \mathrm{~g}, 0.63 \mathrm{mmol}$ ), and 2-methoxycarbonyl-3-hydroxy-5-bromo-indole 11 $(0.210 \mathrm{~g}, 0.79 \mathrm{mmol})$ were mixed in DCM $(8 \mathrm{~mL})$. To this solution was added $12 \mathrm{~mL}$ of a $1 \mathrm{M}$ aqueous solution of $\mathrm{K}_{2} \mathrm{CO}_{3}$. The biphasic (organic:aqueous) reaction mixture was stirred vigorously at room temperature until consumption of the bromide was complete as determined by TLC (1:1 Hex:EtOAc). Afterwards, the organic phase was separated from the aqueous phase; the aqueous phase was extracted with additional DCM $(1 \times 12 \mathrm{~mL})$. The 
combined organic layers were dried with $\mathrm{Na}_{2} \mathrm{SO}_{4}$, filtered, and the and the solvent was removed under reduced pressure. The residue was then purified by column chromatography in the solvent mixtures stated.

5-bromo-2-methoxycarbonyl-indol-3-yl 2,3,4,5,7-penta-O-acetyl- $\beta$-D-glycero-D-guloseptanoside (13). Obtained as brownish oil from 11 and 12 to yield $0.210 \mathrm{~g}(48 \%)$ of $\mathbf{1 3}$. $\mathbf{R}_{f}$ 0.4 (1:1 Hex: EtOAc); ${ }^{1} \mathrm{H}$ NMR $\left(400 \mathrm{MHz} \mathrm{CDCl}_{3}\right) \delta 9.28(\mathrm{~s}, 1 \mathrm{H}), 7.93($ broad s, $1 \mathrm{H}), 7.36(\mathrm{dd}$, $J=8.8,1.8 \mathrm{~Hz}, 1 \mathrm{H}), 7.23(\mathrm{~d}, J=8.8 \mathrm{~Hz}, 1 \mathrm{H}), 5.74(\mathrm{dd}, J=4.7,2.2 \mathrm{~Hz}, 1 \mathrm{H}), 5.64(\mathrm{dd}, J=8.8$, $2.2 \mathrm{~Hz}, 1 \mathrm{H}), 5.49-5.45(\mathrm{~m}, 1 \mathrm{H}), 5.30(\mathrm{~d}, J=4.8 \mathrm{~Hz}, 1 \mathrm{H}), 5.22(\mathrm{dd}, J=9.4,6.0 \mathrm{~Hz}, 1 \mathrm{H}), 4.13$ $(\mathrm{dd}, J=14.3,7.1 \mathrm{~Hz}, 1 \mathrm{H}), 4.08-4.02(\mathrm{~m}, 1 \mathrm{H}), 3.90(\mathrm{~s}, 3 \mathrm{H}), 3.88-3.85(\mathrm{~m}, 1 \mathrm{H}), 2.22(\mathrm{~s}, 3 \mathrm{H}), 2.12$ $(\mathrm{s}, 3 \mathrm{H}), 2.11(\mathrm{~s}, 3 \mathrm{H}), 2.01(\mathrm{~s}, 3 \mathrm{H}), 1.72(\mathrm{~s}, 3 \mathrm{H}) ;{ }^{13} \mathrm{C} \mathrm{NMR}\left(100 \mathrm{MHz}, \mathrm{CDCl}_{3}\right) \delta 170.6,169.5$, 169.4, 169.3, 169.1, 161.4, 139.0, 132.5, 129.2, 123.4, 123.2, 117.0, 113.8, 113.7, 105.4, 73.3, 72.7, 71.2, 70.9, 69.3, 63.5, 60.5, 52.1, 21.0, 20.7, 20.7(2), 20.3, 14.2; HRMS (DART-TOF) $\mathrm{m} / \mathrm{z}$ calcd. for $\mathrm{C}_{27} \mathrm{H}_{30} \mathrm{BrNO}_{12} \mathrm{Na}[\mathrm{M}+\mathrm{Na}]^{+}$694.0747, obs. 694.0743.

5-bromo-2-methoxycarbonyl-indol-3-yl 2,3,4,5,7-penta-O-acetyl- $\beta$-D-glycero-D-ido-septanoside (17). Reaction of 12 with septanosyl bromide 16 using the general procedure gave $0.160 \mathrm{~g}$ $(67 \%)$ of 17 as a brownish syrup. $\mathrm{R}_{f} 0.3\left(3: 2 \mathrm{Hex}\right.$ : EtOAc) ${ }^{1} \mathrm{H}$ NMR $\left(400 \mathrm{MHz}, \mathrm{CDCl}_{3}\right) \delta$ $9.16(\mathrm{~s}, 1 \mathrm{H}), 7.96(\mathrm{~d}, \mathrm{~J}=1.7 \mathrm{~Hz}, 1 \mathrm{H}), 7.37(\mathrm{dd}, \mathrm{J}=8.8,1.8 \mathrm{~Hz}, 1 \mathrm{H}), 7.23(\mathrm{~d}, \mathrm{~J}=8.8 \mathrm{~Hz}, 1 \mathrm{H})$, $5.66(\mathrm{dd}, \mathrm{J}=7.4,2.1 \mathrm{~Hz}, 1 \mathrm{H}), 5.61(\mathrm{~m}, 1 \mathrm{H}), 5.52(\mathrm{~d}, \mathrm{~J}=2.2 \mathrm{~Hz}, 1 \mathrm{H}), 5.40-5.33(\mathrm{~m}, 2 \mathrm{H}), 4.09$ $(\mathrm{dd}, \mathrm{J}=12.2,5.7 \mathrm{~Hz}, 1 \mathrm{H}), 3.98(\mathrm{~s}, 3 \mathrm{H}), 3.94(\mathrm{dd}, \mathrm{J}=12.0,2.2 \mathrm{~Hz}, 1 \mathrm{H}), 3.92(\mathrm{ddd}, \mathrm{J}=11.0$, $5.8,2.2 \mathrm{~Hz}, 1 \mathrm{H}), 2.18(\mathrm{~s}, 3 \mathrm{H}), 2.10(\mathrm{~s}, 3 \mathrm{H}), 2.04(\mathrm{~s}, 3 \mathrm{H}), 1.98(\mathrm{~s}, 3 \mathrm{H}), 1.68(\mathrm{~s}, 3 \mathrm{H}) ;{ }^{13} \mathrm{C} \mathrm{NMR}$ $\left(100 \mathrm{MHz}, \mathrm{CDCl}_{3}\right) \delta 170.8,170.0,169.5,169.2,169.0,161.4,139.6,132.6,129.5,123.4,123.1$, 116.5, 114.0, 113.7, 103.2, 76.4, 72.1, 72.0, 70.5(2), 63.4, 60.6, 52.4, 20.9, 20.7, 20.6(2), 20.3, 14.3; HRMS (DART-TOF) $\mathrm{m} / \mathrm{z}$ calcd. for $\mathrm{C}_{27} \mathrm{H}_{31} \mathrm{BrNO}_{12}[\mathrm{M}+\mathrm{H}]^{+}$672.0928, obs. 672.0923.

Multistep De-acetylation, Decarboxylation, and Acetylation (General Procedure). At room temperature, a solution of approximately $0.3 \mathrm{mmol}$ of the protected indolyl septanoside (i.e., 13 or 17) in $5 \mathrm{~mL} \mathrm{MeOH}$ was treated with a catalytic amount of sodium methoxide (5 mol \%). After starting material disappeared from the TLC (1:1 Hex:EtOAc), indicating that deacetylation was complete, the solvent was removed, and $\mathrm{NaOH}(0.1 \mathrm{M}$ aq.; $14 \mathrm{~mL})$ was added to the residue. The mixture was heated to $40-45{ }^{\circ} \mathrm{C}$ and stirred until $\mathrm{C} 18$ reverse-phase TLC indicated that ester hydrolysis was complete, approximately $4 \mathrm{~h}\left(\mathrm{R}_{\mathrm{f}}\right.$ of the product is 0.7 and starting material is 0.3 in 3:1 water:acetonitrile). The mixture was lyophilized, then $\mathrm{AgOAc}$ (3.0 equiv.), $\mathrm{K}_{2} \mathrm{CO}_{3}$. (6.0 equiv.), and $\mathrm{Ac}_{2} \mathrm{O}(10.0 \mathrm{~mL}$ ) were added. The mixture was heated to $110{ }^{\circ} \mathrm{C}$ for $1 \mathrm{~h}$. Then the mixture was cooled to room temperature and diluted with $20 \mathrm{~mL}$ water and $20 \mathrm{~mL} \mathrm{CH}_{2} \mathrm{Cl}_{2}$. The organic phase was washed with water $(2 \times 20 \mathrm{~mL})$ and dilute aqueous $\mathrm{NaHCO}_{3}(\sim 0.1 \mathrm{M}, 1 \times 20 \mathrm{~mL})$. The organic phase was dried with $\mathrm{Na}_{2} \mathrm{SO}_{4}$, filtered, and the eluent was removed under reduced pressure. The residue was then purified by column chromatography in the solvent stated.

$\mathrm{N}$-Acetyl-5-bromoindol-3-yl 2,3,4,5,7-penta-O-acetyl- $\beta$-D-glycero-D-gulo-septanoside (14). Obtained as a yellowish solid from 13 using the general procedure (73\% yield over 3 steps). $\mathrm{R}_{f} 0.3$ (1:1 Hex:EtOAc) ${ }^{1} \mathrm{H}$ NMR $\left(400 \mathrm{MHz}, \mathrm{CDCl}_{3}\right) \delta 8.25$ (broad s, $\left.1 \mathrm{H}\right), 7.69(\mathrm{~d}$, $J=1.8 \mathrm{~Hz}, 1 \mathrm{H}), 7.46(\mathrm{dd}, J=8.8,1.8 \mathrm{~Hz}, 1 \mathrm{H}), 7.30($ broad s, $1 \mathrm{H}), 5.57-5.54(\mathrm{~m}, 2 \mathrm{H}), 5.44(\mathrm{dd}$, $J=8.0,4.7 \mathrm{~Hz}, 1 \mathrm{H}), 5.15(\mathrm{~d}, J=5.4 \mathrm{~Hz}, 1 \mathrm{H}), 4.33-4.31(\mathrm{~m}, 1 \mathrm{H}), 4.17-4.09(\mathrm{~m}, 3 \mathrm{H}), 2.62(\mathrm{~s}$, $3 \mathrm{H}), 2.20(\mathrm{~s}, 3 \mathrm{H}), 2.14(\mathrm{~s}, 3 \mathrm{H}), 2.13(\mathrm{~s}, 3 \mathrm{H}), 2.06(\mathrm{~s}, 3 \mathrm{H}), 2.03(\mathrm{~s}, 3 \mathrm{H}), 1.93(\mathrm{~s}, 3 \mathrm{H}) ;{ }^{13} \mathrm{C} \mathrm{NMR}$ $\left(100 \mathrm{MHz}, \mathrm{CDCl}_{3}\right) \delta 170.6,169.3(2), 169.2,169.0,168.5,140.0,132.3,129.1,126.1,120.8,118.1$, 117.2, 112.2, 103.5, 74.0, 72.2, 71.6, 70.6, 69.2, 63.7, 60.5, 24.0, 21.2, 21.0, 20.8(2), 20.7, 14.3; HRMS (DART-TOF) $\mathrm{m} / z$ calcd. for $\mathrm{C}_{27} \mathrm{H}_{30} \mathrm{BrNO}_{13} \mathrm{Na}[\mathrm{M}+\mathrm{Na}]^{+} 678.0798$, obs. 678.0785.

$N$-Acetyl-5-bromoindol-3-yl 2,3,4,5,7-penta-O-acetyl- $\beta$-D-glycero-D-ido-septanoside (18). Obtained as yellow solid from 17 using the general procedure (70\% yield over 3 steps) $\mathrm{R}_{f} 0.2$ (3:2 Hex: EtOAc) ${ }^{1} \mathrm{H}$ NMR $\left(400 \mathrm{MHz}, \mathrm{CD}_{3} \mathrm{OD}\right) \delta 8.20(\mathrm{~d}, \mathrm{~J}=8.8 \mathrm{~Hz}, 1 \mathrm{H}), 7.62(\mathrm{~d}$, $\mathrm{J}=1.9 \mathrm{~Hz}, 1 \mathrm{H}), 7.41(\mathrm{dd}, \mathrm{J}=8.8,1.9 \mathrm{~Hz}, 1 \mathrm{H}), 7.37($ broad s, $1 \mathrm{H}), 5.64(\mathrm{~d}, \mathrm{~J}=1.5 \mathrm{~Hz}, 1 \mathrm{H})$, 5.59-5.55 (m, 2H), 5.49-5.45 (m, 1H), $5.36($ app t, J = 9.3 Hz, 1H) $4.33(\mathrm{ddd}, \mathrm{J}=9.2,7.4$, $3.6 \mathrm{~Hz}, 1 \mathrm{H}), 4.23(\mathrm{app} \mathrm{d}, \mathrm{J}=3.6 \mathrm{~Hz}, 2 \mathrm{H}), 2.60(\mathrm{~s}, 3 \mathrm{H}), 2.15(\mathrm{~s}, 3 \mathrm{H}), 2.06(\mathrm{~s}, 3 \mathrm{H}), 2.02(\mathrm{~s}, 3 \mathrm{H})$, $2.00(\mathrm{~s}, 3 \mathrm{H}), 1.76(\mathrm{~s}, 3 \mathrm{H}) ;{ }^{13} \mathrm{C}$ NMR $\left(100 \mathrm{MHz}, \mathrm{CD}_{3} \mathrm{OD}\right) \delta 172.1,171.3,171.0,170.9,170.7$, $170.6,140.9,133.4,129.8,127.3,121.5,119.0,117.7,114.9,112.2,101.6,76.7,73.2,72.7,71.3$, 
71.2, 64.4, 23.9, 20.6(2), 20.5; HRMS (DART-TOF) $m / z$ calcd. for $\mathrm{C}_{27} \mathrm{H}_{30} \mathrm{BrNO}_{13} \mathrm{Na}[\mathrm{M}+\mathrm{Na}]^{+}$ 678.0798, obs. 678.0816 .

Zemplén De-acetylation (General Procedure). A solution of the starting material (1.00 $\mathrm{mmol})$ in $\mathrm{MeOH}(15.0-20.0 \mathrm{~mL})$ was treated with a catalytic amount of sodium methoxide ( $5 \mathrm{~mol} \%)$. The solution was stirred at room temperature overnight $(\sim 16 \mathrm{~h})$. If the product had precipitated during this time it was collected by filtration, otherwise the solution was neutralized with Amberlite IR-120 $(\mathrm{H}+)$ resin ( $\mathrm{pH} 7$ by $\mathrm{pH}$ paper) and then the solution was concentrated to near dryness. The residue was then re-dissolved in a minimum amount of water $(\leq 5.0 \mathrm{~mL})$ and subjected to lyophilization.

5-Bromoindol-3-yl $\beta$-D-glycero-D-gulo-septanoside (8). Obtained from 14 as tan powder after lyophilization using the general procedure (75\% yield). $\mathrm{R}_{f} 0.4$ (4:1 DCM: $\left.\mathrm{MeOH}\right)$ ${ }^{1} \mathrm{H}$ NMR $\left(400 \mathrm{MHz}, \mathrm{CD}_{3} \mathrm{OD}\right) \delta 7.75(\mathrm{~s}, 1 \mathrm{H}), 7.23(\mathrm{~s}, 1 \mathrm{H}), 7.19(\mathrm{~d}, J=8.7 \mathrm{~Hz}, 1 \mathrm{H}), 7.14(\mathrm{~d}$, $J=8.7 \mathrm{~Hz}, 1 \mathrm{H}), 4.99(\mathrm{~s}, 6 \mathrm{H}), 4.93(\mathrm{~d}, J=5.5 \mathrm{~Hz}, 1 \mathrm{H}), 4.21(\mathrm{app} \mathrm{t}, J=4.4 \mathrm{~Hz}, 1 \mathrm{H}), 3.89(\mathrm{dd}$, $J=9.1,3.3 \mathrm{~Hz}, 1 \mathrm{H}), 3.86-3.79(\mathrm{~m}, 2 \mathrm{H}), 3.66-3.60(\mathrm{~m}, 2 \mathrm{H}), 3.46($ app t, $J=7.9 \mathrm{~Hz}, 1 \mathrm{H}) ;{ }^{13} \mathrm{C}$ NMR (100 MHz, CD3OD) 8 137.9, 133.9, 125.6, 123.2, 121.0, 114.2(2), 112.7, 110.1, 82.3, 75.6, 75.5, 73.9, 72.2, 64.4; HRMS (DART-TOF) $m / z$ calcd. for $\mathrm{C}_{15} \mathrm{H}_{19} \mathrm{BrNO}_{7}[\mathrm{M}+\mathrm{H}]^{+} 404.0345$, obs. 404.0338 .

5-Bromoindol-3-yl $\beta$-D-glycero-D-ido-septanoside (9). Obtained as light brown solid from 18 using the general procedure $\left(79 \%\right.$ yield) $\mathrm{R}_{f} 0.4(4: 1 \mathrm{DCM}: \mathrm{MeOH}){ }^{1} \mathrm{H}$ NMR $\left(400 \mathrm{MHz}, \mathrm{CD}_{3} \mathrm{OD}\right) \delta 7.87(\mathrm{~s}, 1 \mathrm{H}), 7.78(\mathrm{~d}, J=1.8 \mathrm{~Hz}, 1 \mathrm{H}), 7.20(\mathrm{~m}, 1 \mathrm{H}), 7.16(\mathrm{dd}, J=8.6$, $1.8 \mathrm{~Hz}, 1 \mathrm{H}), 5.09(\mathrm{~d}, J=2.3 \mathrm{~Hz}, 1 \mathrm{H}), 4.88(\mathrm{~s}, 6 \mathrm{H}), 4.00(\mathrm{dd}, J=6.3,2.2 \mathrm{~Hz}, 1 \mathrm{H}), 3.86-3.83(\mathrm{~m}$, $1 \mathrm{H}), 3.71-3.66(\mathrm{~m}, 2 \mathrm{H}), 3.61(\mathrm{dd}, J=14.1,7.0 \mathrm{~Hz}, 1 \mathrm{H}), 3.52-3.50(\mathrm{~m}, 2 \mathrm{H}) ;{ }^{13} \mathrm{C}$ NMR $(100 \mathrm{MHz}$, $\left.\mathrm{CD}_{3} \mathrm{OD}\right) \delta 137.7,133.9,125.7,123.3,121.1,114.2(2), 112.8,105.5,83.2,76.7,75.7,75.5,74.1$, 64.3; HRMS (DART-TOF) $\mathrm{m} / z$ calcd. for $\mathrm{C}_{15} \mathrm{H}_{18} \mathrm{BrNO}_{7} \mathrm{Na}[\mathrm{M}+\mathrm{Na}]^{+} 426.0164$, obs. 426.0204 .

\subsection{Synthesis of BODIPY-Labeled Septanoside $\mathbf{2 3}$}

BODIPY:2,3,4,5,7-Penta-O-acetyl- $\beta$-D-glycero-D-gulo-septanosyl azide conjugate (22). BODIPY-FL alkyne $20(0.0025 \mathrm{~g}, 0.008 \mathrm{mmol})$ and septanosyl azide $21(0.0085 \mathrm{~g}, 0.02 \mathrm{mmol})$ and were dissolved in a mixture of THF:water (1 mL of 3:1 mixture). A solution of $\mathrm{CuSO}_{4} \cdot 5 \mathrm{H}_{2} \mathrm{O}(0.001 \mathrm{~g}$, 0.5 eq.) and sodium ascorbate $(0.0012 \mathrm{~g}, 0.8$ eq.) in an additional $1 \mathrm{~mL}$ of the THF:water was sonicated for $10 \mathrm{~min}$ and then added to the initial alkyne-azide solution. The mixture was allowed to react at room temperature with stirring for $12 \mathrm{~h}$. After, the reaction mixture was diluted with $5 \mathrm{~mL}$ EtOAc and the aqueous and organic layers separated; the aqueous layer was then extracted with additional EtOAc $(2 \times 5 \mathrm{~mL})$. The combined organic layers were dried over $\mathrm{Na}_{2} \mathrm{SO}_{4}$, filtered, and the solvent was evaporated under reduced pressure. The crude product was then purified by column chromatography to deliver 20 as brownish oil ( $0.0028 \mathrm{~g}$, 48\% yield) $\mathrm{R}_{f} 0.4$ (3:2 Hex: EtOAc); ${ }^{1} \mathrm{H}$ NMR $\left(400 \mathrm{MHz}, \mathrm{CDCl}_{3}\right) \delta 7.09(\mathrm{~s}, 1 \mathrm{H}), 6.88(\mathrm{~d}, J=3.9 \mathrm{~Hz}, 1 \mathrm{H}), 6.28(\mathrm{~d}, J=4.0 \mathrm{~Hz}, 1 \mathrm{H}), 6.12(\mathrm{~s}$, 1H), $5.82($ broad s, $1 \mathrm{H}), 5.40(\mathrm{dd}, J=8.0,1.9 \mathrm{~Hz}, 2 \mathrm{H}), 5.34(\mathrm{dd}, J=8.0,3.9 \mathrm{~Hz}, 2 \mathrm{H}), 5.10(\mathrm{dd}$, $J=6.5,1.9 \mathrm{~Hz}, 2 \mathrm{H}), 5.05-5.00(\mathrm{~m}, 2 \mathrm{H}), 4.18-4.12(\mathrm{~m}, 3 \mathrm{H}), 3.28(\mathrm{t}, J=7.5 \mathrm{~Hz}, 2 \mathrm{H}), 2.67-2.63$ $(\mathrm{m}, 2 \mathrm{H}), 2.57(\mathrm{~s}, 3 \mathrm{H}), 2.26(\mathrm{~s}, 3 \mathrm{H}), 2.12(\mathrm{~s}, 3 \mathrm{H}), 2.11(\mathrm{~s}, 9 \mathrm{H}), 2.09(\mathrm{~s}, 3 \mathrm{H}) ;{ }^{13} \mathrm{C} \mathrm{NMR}(100 \mathrm{MHz}$, $\left.\mathrm{CDCl}_{3}\right) \delta 171.5,170.8,169.3,169.1$ (2), 128.5, 124.0, 120.7, 117.7, 91.3, 79.7, 77.4, 76.0, 72.1, 71.8, 71.6, 70.6, 69.4, 64.3, 36.1, 29.9, 29.4, 25.0, 20.9 (3), 15.2, 11.5;HRMS (DART-TOF) $\mathrm{m} / \mathrm{z}$ calcd. for $\mathrm{C}_{34} \mathrm{H}_{41} \mathrm{BF}_{2} \mathrm{~N}_{6} \mathrm{O}_{12} \mathrm{Na}[\mathrm{M}+\mathrm{Na}]^{+}$797.2730, obs. 797.2725.

BODIPY: $\beta$-D-glycero-D-gulo-septanosyl azide conjugate (23). A solution of starting per$O$-acetylated BODIPY conjugate $22(0.0028 \mathrm{~g}, 0.004 \mathrm{mmol})$ was dissolved in dry methanol $(0.75 \mathrm{~mL})$ and kept under an inert atmosphere and dark conditions. To this solution was added $5 \mathrm{~mol} \%$ of $\mathrm{NaOMe}$ in $\mathrm{MeOH}$. The reaction was stirred at room temperature for $12 \mathrm{~h}$ and monitored by TLC ( $\mathrm{R}_{f}$ of the product is 0.1 and starting material is 0.5 in 1:1 $\mathrm{Hex} / \mathrm{EtOAc})$. Upon complete disappearance of the starting material, the reaction solvent was evaporated under the reduced pressure and the residue was re-dissolved in de-ionized water $(1.00 \mathrm{~mL})$ and subjected to lyophilization to obtain $\mathbf{2 3}$ as a brownish solid. The crude product was used in confocal microscopy experiments without further purification. 


\subsection{Glycosidase Activity Assay on E. coli Cells}

Twenty microliters of $100 \mathrm{mM}$ IPTG solution in water and $20 \mu \mathrm{L}$ of a $20 \mathrm{mg} / \mathrm{mL}$ X-Gal (5) or X-Sept (8) solution in DMF were spread on LB agar Petri plates (20 mL medium) containing kanamycin $(100 \mu \mathrm{g} / \mathrm{mL})$ and allowed to dry for $20 \mathrm{~min}$ at $37^{\circ} \mathrm{C}$. Competent BL21 (DE3) Star cells were transformed (chemically competent cells [37]) with plasmid pRSF- $\beta$-gal encoding the E. coli $\beta$-galactosidase and spread onto the agar plates. Color development was analyzed after $24 \mathrm{~h}$ incubation at $37^{\circ} \mathrm{C}$.

\subsection{Probing Glycoside Hydrolases for Septanoside Hydrolysis}

Activity assays were performed at the optimal $\mathrm{pH}$ and temperature for each enzyme as indicated in Table 1. Indolyl substrates $\mathbf{8}$ and $\mathbf{9}(1 \mathrm{mM})$ and enzymes (concentration ranging from 25 to $50 \mathrm{U} / \mathrm{mL}$ ) in buffer were incubated in $1 \mathrm{~mL}$ cuvettes and the absorbance monitored at $630 \mathrm{~nm}$. Specific activities of the commercial enzymes with pNP substrates are from the manufacturer, and $\beta$-glucosidase Bgl3 from Streptomyces sp. as reported [30].

\subsection{Kinetics of Streptomyces $\beta$-Glucosidase with p-Nitrophenyl Septanoside $\mathbf{1 9}$}

Kinetics were performed by monitoring $p$ NP release by absorbance at $400 \mathrm{~nm}$. Reactions were done in thermostated cuvettes at $50{ }^{\circ} \mathrm{C}$ in $50 \mathrm{mM}$ phosphate buffer $\mathrm{pH} 6.5$ with $0.1-10 \mathrm{mM}$ substrates and $46 \mathrm{nM}$ enzyme (Bgl3) for $p$ NP-Glc or $9.2 \mu \mathrm{M} \mathrm{Bgl3} \mathrm{for}$ $p$ NP-septanoside (19). Rates were obtained from the initial slopes after subtracting the blank rates (in the absence of enzyme) and kinetic constants were calculated from data fitted to a Michaelis-Menten equation with substrate inhibition (Equation (1)) for $p$ NP-Glc and to a sigmoidal equation (Equation (2)) for $p$ NP-Sept (19) using GraphPad software (Prism, San Diego, CA, USA).

$$
\begin{gathered}
v=k_{\text {cat }}[E]_{0}[S] /\left(K_{M}+[S]+[S]^{2} / K_{i}\right) \\
v=k_{\text {cat }}[E]_{0}[S]^{h} /\left(K_{M}^{h}+[S]^{h}\right)
\end{gathered}
$$

where $[S]$ is the substrate concentration, $[E]_{0}$ the enzyme concentration, and $k_{\text {cat }}$ (catalytic constant), $K_{M}$ (Michaelis constant), $K_{i}$ (substrate inhibition constant) and h (Hill index) are the adjustable parameters [38].

\subsection{Cell Internalization of Compound $\mathbf{2} 3$ by Confocal Microscopy}

E. coli MG1655 cultures were grown to an $\mathrm{OD}_{600}$ of $\sim 1.0\left(1 \times 10^{9} \mathrm{cfu} / \mathrm{mL}\right)$ in Luria Broth (LB), washed, and suspended in $10 \mathrm{mM}$ MES buffer $\mathrm{pH} 5.5$ to a final $\mathrm{OD}_{600}=1$. To $100 \mu \mathrm{L}$ of cell suspension (different dilutions tested, best results with a 1:2 dilution), BODIPY-septanoside 23 was added to a final $1 \mu \mathrm{M}$ concentration with shaking. Cells were incubated for $1 \mathrm{~h}$ at $37{ }^{\circ} \mathrm{C}$. Then, $1 \mu \mathrm{L}$ FM 4-64 $(1 \mu \mathrm{g} / \mathrm{mL}$ stock) and $1 \mu \mathrm{L}$ DAPI $\left(2 \mu \mathrm{g} / \mathrm{mL}\right.$ stock) were added to the cells with shaking and incubated for $30 \mathrm{~min}$ at $37^{\circ} \mathrm{C}$ for membrane and DNA staining, respectively. Cells were spun down by centrifugation for $60 \mathrm{~s}$ and resuspended in 1/10 their original volume. Three microliters of cell suspension were spotted onto $1.5 \%$ agarose pads containing solid LB medium. The cells were then imaged using a Nikon A1R spectral confocal microscope with a $60 \times$ oil immersion lens.

Supplementary Materials: The following are available online at https:/ /www.mdpi.com/article/10 $.3390 /$ ijms22094497/s1.

Author Contributions: A.R.P. and S.P., experimental and data analysis; and A.P. and M.W.P., conceptualization, supervision, and writing and acquisition of funding. All authors have read and agreed to the published version of the manuscript.

Funding: This work was supported by NSF grant CHE-1506567 (to M.W.P.) and grant PID2019104350RB-I00 from MICINN, Spain (to A.P.).

Institutional Review Board Statement: Not applicable. 
Informed Consent Statement: Not applicable.

Data Availability Statement: The data that support the findings of this study are available from the corresponding authors upon reasonable request.

Acknowledgments: S.P. acknowledges a predoctoral contract from MICINN, Spain. We thank Alfredo Angeles-Boza and Samuel Juliano (UConn) for their support on confocal microscopy experiments.

Conflicts of Interest: The authors declare no conflict of interest.

\section{References}

1. Pallister, E.; Gray, C.J.; Flitsch, S.L. Enzyme promiscuity of carbohydrate active enzymes and their applications in biocatalysis. Curr. Opin. Struct. Biol. 2020, 65, 184-192. [CrossRef]

2. Kytidou, K.; Artola, M.; Overkleeft, H.S.; Aerts, J.M.F.G. Plant Glycosides and Glycosidases: A Treasure-Trove for Therapeutics. Front. Plant Sci. 2020, 11. [CrossRef] [PubMed]

3. Gloster, T.M. Exploitation of carbohydrate processing enzymes in biocatalysis. Curr. Opin. Chem. Biol. 2020, 55, 180-188. [CrossRef]

4. Davies, G.J.; Planas, A.; Rovira, C. Conformational Analyses of the Reaction Coordinate of Glycosidases. Acc. Chem. Res. 2012, 45, 308-316. [CrossRef]

5. Sinnott, M.L. Catalytic Mechanisms of Enzymic Glycosyl Transfer. Chem. Rev. 1990, 90, 1171-1202. [CrossRef]

6. Lombard, V.; Golaconda Ramulu, H.; Drula, E.; Coutinho, P.M.; Henrissat, B. The carbohydrate-active enzymes database (CAZy) in 2013. Nucleic Acids Res. 2014, 42, D490-D495. [CrossRef] [PubMed]

7. Dey, S.; Samanta, G.C.; Jayaraman, N. Advancements in synthetic and structural studies of septanoside sugars. In Recent Trends in Carbohydrate Chemistry; Rauter, A.P., Christensen, B., Somsak, L., Kosma, P., Adamo, R., Eds.; Elsevier Inc.: Amsterdam, The Netherlands, 2020; pp. 217-251.

8. Saha, J.; Peczuh, M.W. Synthesis and properties of septanose carbohydrates. In Advances in Carbohydrate Chemistry and Biochemistry; Academic Press: Cambridge, MA, USA, 2011; Volume 66, pp. 121-186.

9. Ben Nejma, A.; Nguir, A.; Ben Jannet, H.; Hamza, M.A.; Daïch, A.; Othman, M.; Lawson, A.M. New septanoside and 20hydroxyecdysone septanoside derivative from Atriplex portulacoides roots with preliminary biological activities. Bioorg. Med. Chem. Lett. 2015, 25, 1665-1670. [CrossRef]

10. Le Merrer, Y.; Poitout, L.; Depezay, J.C.; Dosbaa, I.; Geoffroy, S.; Foglietti, M.J. Synthesis of azasugars as potent inhibitors of glycosidases. Bioorg. Med. Chem. 1997, 5, 519-533. [CrossRef]

11. Tauss, A.; Steiner, A.J.; Stütz, A.E.; Tarling, C.A.; Withers, S.G.; Wrodnigg, T.M. L-Idoseptanosides: Substrates of D-glucosidases? Tetrahedron Asymmetry 2006, 17, 234-239. [CrossRef]

12. Elshahawi, S.I.; Shaaban, K.A.; Kharel, M.K.; Thorson, J.S. A comprehensive review of glycosylated bacterial natural products. Chem. Soc. Rev. 2015, 44, 7591-7697. [CrossRef]

13. Guo, Z.; Tang, Y.; Tang, W.; Chen, Y. Heptose-containing bacterial natural products: Structures, bioactivities, and biosyntheses Nat. Prod. Rep. 2021. [CrossRef]

14. Tang, W.; Guo, Z.; Cao, Z.; Wang, M.; Li, P.; Meng, X.; Zhao, X.; Xie, Z.; Wang, W.; Zhou, A.; et al. D-Sedoheptulose-7-phosphate is a common precursor for the heptoses of septacidin and hygromycin B. Proc. Natl. Acad. Sci. USA 2018, 115, 2818-2823. [CrossRef]

15. Horwitz, J.P.; Chua, J.; Cubby, R.J.; Tomson, A.J.; Da Rooge, M.A.; Fisher, B.E.; Mauricio, J.; Klundt, I. Substrates for Cytochemical

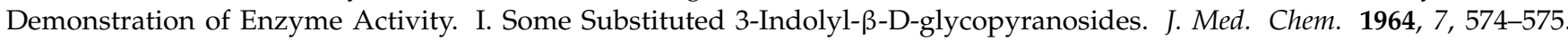
[CrossRef] [PubMed]

16. Miller, J.H. Experiments in Molecular Genetics, 1st ed.; Cold Spring Harbor Laboratory Press: Cold Spring Harbor, NY, USA, 1972.

17. Kiernan, J. Indigogenic substrates for detection and localization of enzymes. Biotech. Histochem. 2007, 82, 73-103. [CrossRef] [PubMed]

18. Böttcher, S.; Thiem, J. Indoxylic Acid Esters as Convenient Intermediates Towards Indoxyl Glycosides. Eur. J. Org. Chem. 2014, 2014, 564-574. [CrossRef]

19. Wolk, J.L.; Frimer, A.A. A simple, safe and efficient synthesis of Tyrian purple (6,6'-Dibromoindigo). Molecules 2010, 15, 5561-5580. [CrossRef]

20. Castro, S.; Duff, M.; Snyder, N.L.; Morton, M.; Kumar, C.V.; Peczuh, M.W. Recognition of septanose carbohydrates by concanavalin A. Org. Biomol. Chem. 2005, 3, 3869-3872. [CrossRef]

21. Duff, M.R.; Fyvie, W.S.; Markad, S.D.; Frankel, A.E.; Kumar, C.V.; Gascón, J.A.; Peczuh, M.W. Computational and experimental investigations of mono-septanoside binding by Concanavalin A: Correlation of ligand stereochemistry to enthalpies of binding. Org. Biomol. Chem. 2011, 9, 154-164. [CrossRef]

22. Sager, C.P.; Fiege, B.; Zihlmann, P.; Vannam, R.; Rabbani, S.; Jakob, R.P.; Preston, R.C.; Zalewski, A.; Maier, T.; Peczuh, M.W.; et al. The price of flexibility—a case study on septanoses as pyranose mimetics. Chem. Sci. 2018, 9, 646-654. [CrossRef]

23. Nagata, S.; Tomida, H.; Iwai-Hirose, H.; Tanaka, H.N.; Ando, H.; Imamura, A.; Ishida, H. Synthesis of a 1,2-: Cis -indoxyl galactoside as a chromogenic glycosidase substrate. RSC Adv. 2019, 9, 28241-28247. [CrossRef] 
24. Böttcher, S.; Thiem, J. Synthesis of indoxyl-glycosides for detection of glycosidase activities. J. Vis. Exp. 2015, 2015, e52442. [CrossRef]

25. Böttcher, S.; Hederos, M.; Champion, E.; Dékány, G.; Thiem, J. Novel efficient routes to indoxyl glycosides for monitoring glycosidase activities. Org. Lett. 2013, 15, 3766-3769. [CrossRef]

26. Pote, A.R.; Vannam, R.; Richard, A.; Gascón, J.; Peczuh, M.W. Formation of and Glycosylation with Per-O-Acetyl Septanosyl Halides: Rationalizing Complex Reactivity En Route to p-Nitrophenyl Septanosides. Eur. J. Org. Chem. 2018, 2018, 1709-1719. [CrossRef]

27. de Melo, J.S.S.; Rondão, R.; Burrows, H.D.; Melo, M.J.; Navaratnam, S.; Edge, R.; Voss, G. Spectral and Photophysical Studies of Substituted Indigo Derivatives in Their Keto Forms. ChemPhysChem 2006, 7, 2303-2311. [CrossRef]

28. Rajesh, K.; Somasundaram, M.; Saiganesh, R.; Balasubramanian, K.K. Bromination of deactivated aromatics: A simple and efficient method. J. Org. Chem. 2007, 72, 5867-5869. [CrossRef] [PubMed]

29. Imming, P.; Imhof, I.; Zentgraf, M. An improved synthetic procedure for 6,6'-dibromoindigo (Tyrian Purple). Synth. Commun. 2001, 31, 3721-3727. [CrossRef]

30. Vallmitjana, M.; Ferrer-Navarro, M.; Planell, R.; Abel, M.; Ausín, C.; Querol, E.; Planas, A.; Pérez-Pons, J.A. Mechanism of the family $1 \beta$-glucosidase from Streptomyces sp: Catalytic residues and kinetic studies. Biochemistry 2001, 40, 5975-5982. [CrossRef] [PubMed]

31. Stroobants, A.; Portetelle, D.; Vandenbol, M. New carbohydrate-active enzymes identified by screening two metagenomic libraries derived from the soil of a winter wheat field. J. Appl. Microbiol. 2014, 117, 1045-1055. [CrossRef] [PubMed]

32. Kowada, T.; Maeda, H.; Kikuchi, K. BODIPY-based probes for the fluorescence imaging of biomolecules in living cells. Chem. Soc. Rev. 2015, 44, 4953-4972. [CrossRef]

33. Uppal, T.; Bhupathiraju, N.V.S.D.K.; Vicente, M.G.H. Synthesis and cellular properties of Near-IR BODIPY-PEG and carbohydrate conjugates. Tetrahedron 2013, 69, 4687-4693. [CrossRef]

34. Aharoni, A.; Thieme, K.; Chiu, C.P.C.; Buchini, S.; Lairson, L.L.; Chen, H.; Strynadka, N.C.J.; Wakarchuk, W.W.; Withers, S.G. High-throughput screening methodology for the directed evolution of glycosyltransferases. Nat. Methods 2006, 3, 609-614. [CrossRef] [PubMed]

35. Liu, B.; Novikova, N.; Simpson, M.C.; Timmer, M.S.M.; Stocker, B.L.; Söhnel, T.; Ware, D.C.; Brothers, P.J. Lighting up sugars: Fluorescent BODIPY-: Gluco -furanose and -septanose conjugates linked by direct B-O-C bonds. Org. Biomol. Chem. 2016, 14, 5205-5209. [CrossRef] [PubMed]

36. Kolb, H.C.; Finn, M.G.; Sharpless, K.B. Click Chemistry: Diverse Chemical Function from a Few Good Reactions. Angew. Chem. Int. Ed. 2001, 40, 2004-2021. [CrossRef]

37. Green, M.R.; Hughes, H.; Sambrook, J.; MacCallum, P. Molecular Cloning; A Laboratory Manual, 4th ed.; Cold Spring Harbor Laboratory Press: Cold Spring Harbor, NY, USA, 2012.

38. Segel, I.H. Enzyme Kinetics: Behaviour and Analysis of Rapid Equilibrium and Steady-State Enzyme Systems; John Wiley \& Sons Ltd.: New York, NY, USA, 1975. 